\title{
Perancangan Sistem Informasi Pada Karya Agung Furnitur
}

\author{
Yudi Wiharto ${ }^{1}$, Ari Irawan ${ }^{2}$
}

\begin{abstract}
Abstrak- Sistem Informasi adalah sebuah kombinasi dari teknologi informasi dan aktivitas orang yang menggunakan teknologi tersebut untuk mendukung operasi dan manajemen. Dalam arti yang luas, istilah sistem informasi yang sering digunakan merujuk kepada interaksi antar manusia, proses algoritma, data, informasi dan teknologi. Dalam istilah ini, digunakan untuk merujuk tidak hanya pada penggunaan organisasi teknologi informasi dan komunikasi (TIK), tetapi juga untuk di mana orang-orang berinteraksi dengan teknologi ini dalam mendukung suatu proses bisnis.
\end{abstract}

Kata kunci: Teknologi, Sistem Informasi, Furniture.

\section{PENDAHULUAN}

Perkembangan teknologi informasi yang semakin pesat di era ini, telah menciptakan persaingan antar perusahaan menjadi semakin besar. Sehingga menuntut suatu sistem informasi yang tepat, cepat, dan akurat dalam memperoleh informasi yang berguna bagi perkembangan usaha suatu perusahaan. Berdasarkan fakta yang ada, kesadaran tentang peranan teknologi informasi juga semakin meluas di semua lingkup pekerjaan manusia, dan hal itu terjadi secara merata diseluruh belahan dunia. Dengan adanya teknologi informasi akan mempermudah dalam memperoleh informasi yang tepat, cepat, dan akurat. Karena itu diperlukan suatu wujud teknologi informasi yaitu komputer, pemakaian komputer sebagai alat pengolah data dapat dikatakan yang terbaik untuk saat ini, karena dapat memudahkan pekerjaan sehingga dapat lebih efisiensi, akurat dan cepat dalam mengolah data.

Sistem yang terdapat pada Karya AgungFurnitur belum menggunakan sistem yang terkomputerisasi atau masih dilakukan secara manual dengan menggunakan buku besar. Namun dengan sistem yang terkomputerisasi tidak selalu dapat melakukan pekerjaan dengan sempurna, tapi tingkat

Received: 5 Februari 2018; Revised: 1 Maret 2018; Accepted: 1 April 2018

Y.Wiharto, Universitas Budi Luhur (visited.mymail@gmail.com)

A. Irawan., ${ }^{2}$ Universitas Tanri Abeng (2ari_irawan@tau.ac.id). kesempurnaan yang dicapai oleh sistem yang sudah komputerisasi akan jauh lebih baik jika dibandingkan dengan sistem yang masih dikelola secara manual.Keterbatasan yang ada pada sistem manual dapat menimbulkan berbagai hambatan di antaranya kesalahan dalam mencatat, hilangnya data atau dokumen yang terselip. Apabila kondisi itu dibiarkan berlarut-larut, maka harapan untuk meningkatkan suatu produktivitas dalam perusahaan tidak dapat terpenuhi dan pelayanan pada konsumen kurang efektif. Hal tersebutlah yang mendasari peneliti untuk mencoba merancang sistem informasi pada Karya Agung Furnitur, supaya dapat meningkatkan kinerja perusahaan tersebut pada masa yang akan datang

\section{METODE PENELITIAN}

Untuk menyelesaikan penelitian ini diperlukan pengumpulan data yang berhubungan dengan masalah yang dibahas. Tujuannya sebagai sumber landasan pembahasan dan pembuatan rancangan sistem. Adapun metode penelitian yang digunakan dalam mengumpulkan data atau materi penulisan adalah dengan cara:

A. Pengamatan (observasi)

Pengamatan atau observasi merupakan salah satu teknik pengumpulan data/fakta yang cukup efektif untuk mempelajari suatu sistem. Pengamatan langsung ini dilakukan untuk mengetahui proses-proses yang sedang berjalan serta membuat keputusan yang menyangkut lingkungan fisiknya pada suatu kegiatan yang sedang berjalan.

B. Wawancara (interview)

Wawancara dilakukan untuk mendapatkan data dan informasi dalam bentuk tanya jawab kepada orang yang terlibat secara langsung dengan sistem penjualan tunai yang merupakan obyek penelitian.

C. Dokumentasi

Dokumentasi merupakan himpunan atau kumpulan bahan atau dokumen yang dapat digunakan sebagai sumber penelitian. Contoh: surat pesanan, surat jalan, retur pembelian dan sebagainya.

D. Studi Pustaka

Metode ini menggunakan dokumen sebagai sumber bacaan, baik buku-buku ilmiah maupun jurnal, terutama yang erat hubungannya dengan masalah yang di bahas dalam penelitian ini. 
I.

\section{RUANG LINGKUP}

Karya Agung Furnitur merupakan usaha yang bergerak dalam bidang furniture. Barang-barang yang tersedia di Karya Agung Furnitur adalah meubel, lemari, kitchen set, meja belajar dan kebutuhan furniture lainnya. Prosedur yang menggambarkan kegiatan yang terjadi dalam sistem penjualan tunai di Karya Agung Furnitur adalah sebagai berikut:

A. Seorang Customer datang ke toko dan memilih barang yang diinginkan. Setelah mendapatkan informasi dari Sales Promotion Girl/Sales Promotion Man (SPG/SPM) tentang fungsi dan kondisi barang, maka SPG/SPM melakukan transaksi dengan memberikan fix price terbaik yang memberikan kepastian harga kepada Customer dalam berbelanja. Kemudian jika sudah mendapatkan kesepakatan harga yang diinginkan, kasir akan membuatkan faktur yang terdiri dari tiga rangkap yaitu berwarna putih, merah dan kuning.

B. Customer diperbolehkan untuk membayar tunai ataupun dengan sistem uang muka sesuai dengan yang disepakati, tetapi jika Customer langsung membawa pulang barang tersebut, maka Customer diharuskan membayar tunai.

C. Customer yang membayar tunai, akan menerima faktur yang berwarna putih dari kasir. Sementara Customer yang membayar dengan sistem uang muka, akan menerima faktur yang berwarna merah dari kasir.

D. Staf pengiriman akan mengirimkan barang yang tidak dapat dibawa pulang sendiri. Customer yang membayar dengan sistem uang muka dan telah menerima barang yang dikirim dalam kondisi baik, berkewajiban melunasi sisa pembayaran dan menandatangani surat jalan/faktur. Kemudian staf memberikan surat jalan/faktur yang berwarna putih kepada Customer dan meminta kembali surat jalan/faktur yang berwarna merah.

E. Customer yang telah membayar tunai tetapi barangnya harus dikirim, akan menerima surat jalan/faktur berwarna merah untuk ditanda tangani oleh Customer sebagai bukti telah menerima barang dengan kondisi baik.

F. Setelah mengantarkan barang kepada Customer, staf tersebut kemudian memberikan surat jalan/faktur yang berwarna merah dan sisa pembayaran dari Customer yang membayar dengan sistem uang muka kepada kasir.

G. Kemudian kasir menyimpan surat jalan/faktur yang berwarna merah dan kuning sebagai arsip untuk membuat laporan penjualan setiap bulannya.

H.

\section{ATURAN BISNIS}

Aturan bisnis haruslah menjadi bagian dari model data logika untuk meyakinkan bahwa pada program tidak hanya terdapat struktur data namun juga ada nilai kebenaran data yang merefleksikan operasi bisnis. Adapun aturan bisnis yang terdapat pada Karya Agung Furnitur antara lain:

a. Memperbolehkan Customer untuk membayar dengan sistem uang muka dengan syarat tertentu.

b. Barang yang sudah dibeli tidak dapat dikembalikan. c. Jika terjadi kerusakan dalam pengiriman barang, maka akan menjadi tanggung jawab Karya Agung Furnitur.

\section{SISTEM USULAN}

A. Use Case Diagram

1) Use Case Diagram File Master

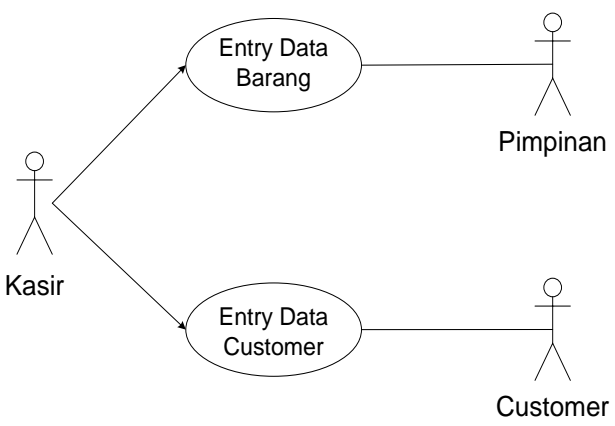

Gambar 1.Use Case Diagram File Master

2) Use Case Diagram Transaksi

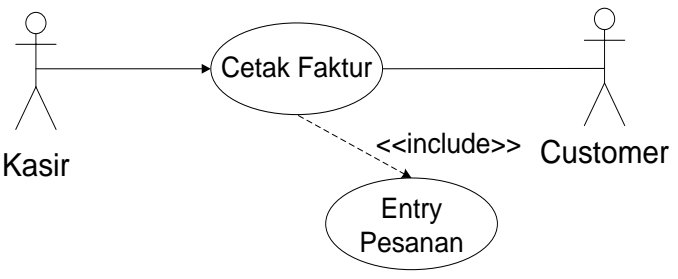

Gambar 2.Use Case Diagram Transaksi(1)

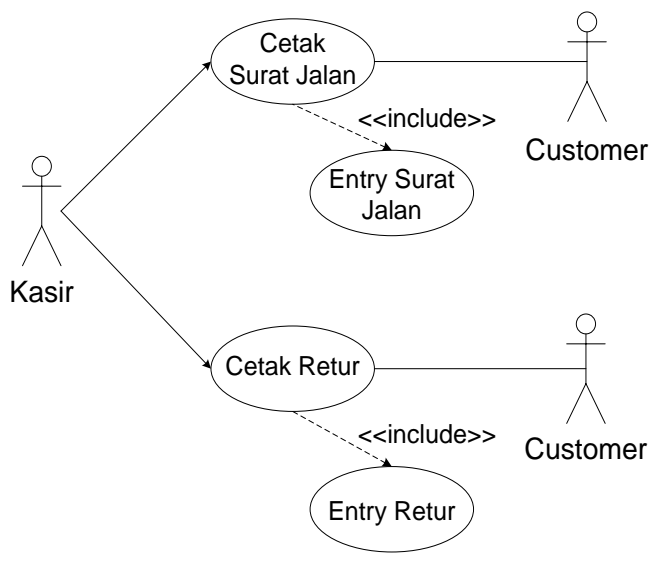

Gambar 3.Use Case Diagram Transaksi (2)

3) Use Case Diagram Laporan 


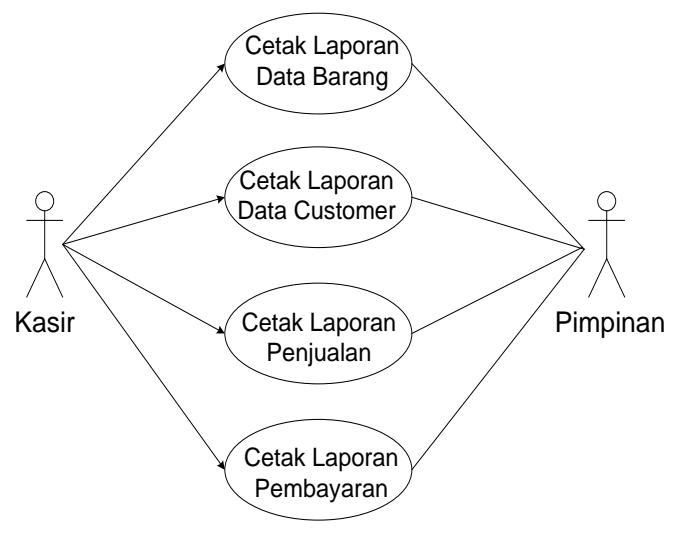

Gambar4. Use Case Diagram Laporan

B. Rancangan Basis Data

1) Permodelan Data Konseptual

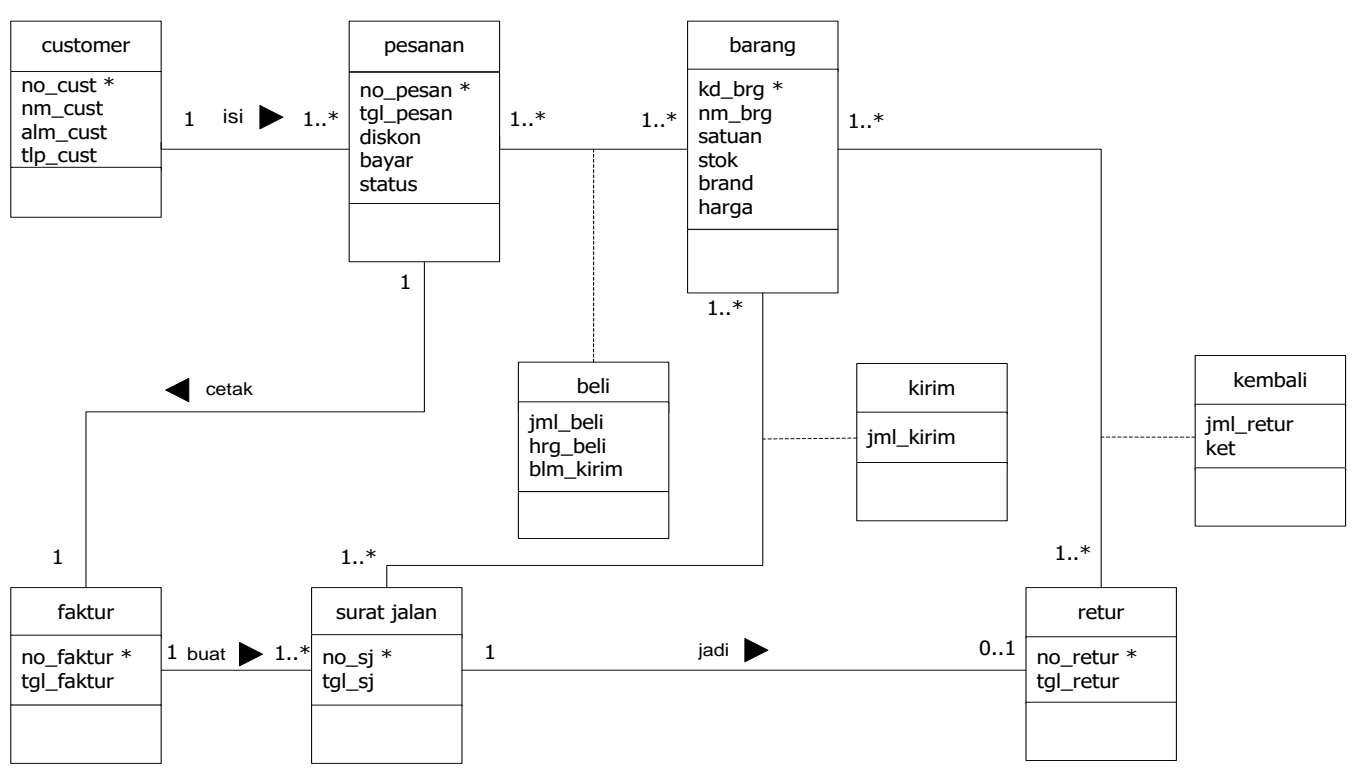

Gambar 5.Permodelan Data Konseptual

\section{2) Logical Record Structure}


Perancangan Sistem Informasi Pada Karya Agung Furnitur

Y. Wiharto, A. Irawan

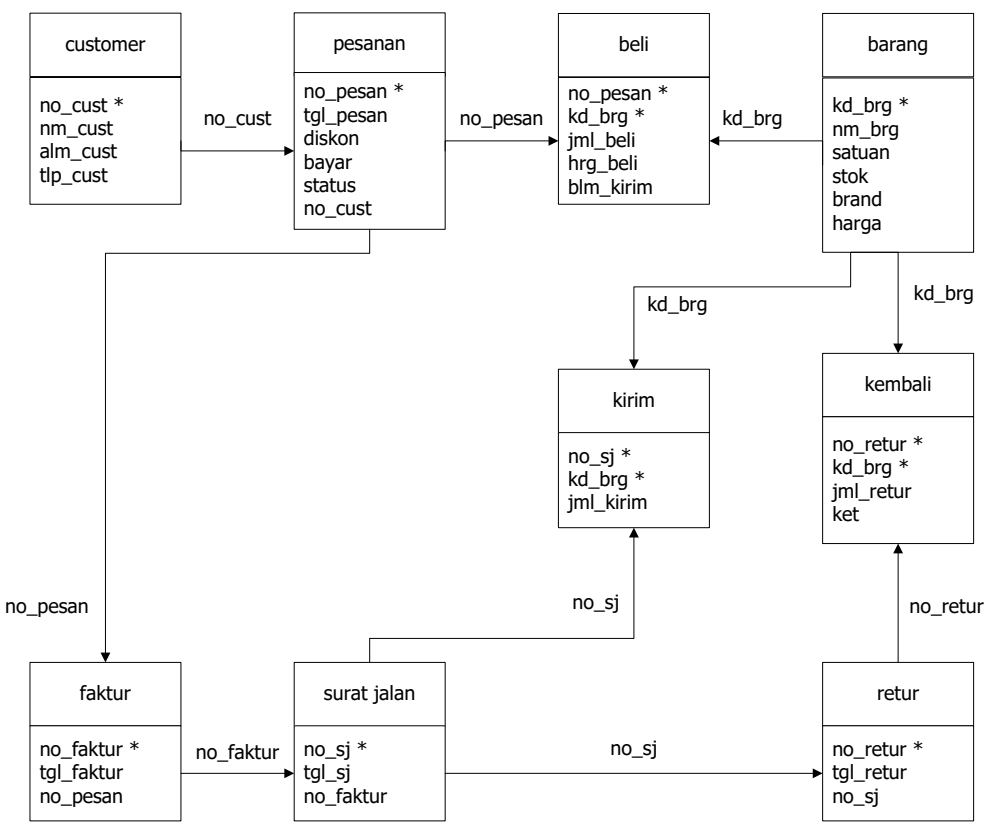

Gambar 6.Logical Record Structure

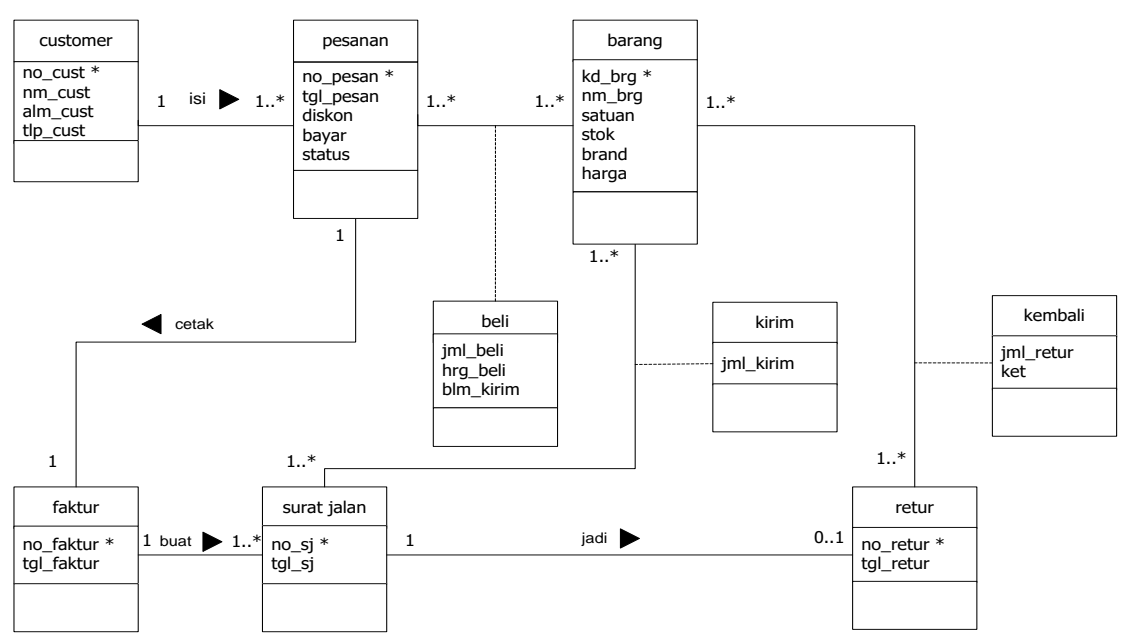

Gambar 5.Permodelan Data Konseptual

\section{3) Logical Record Structure}




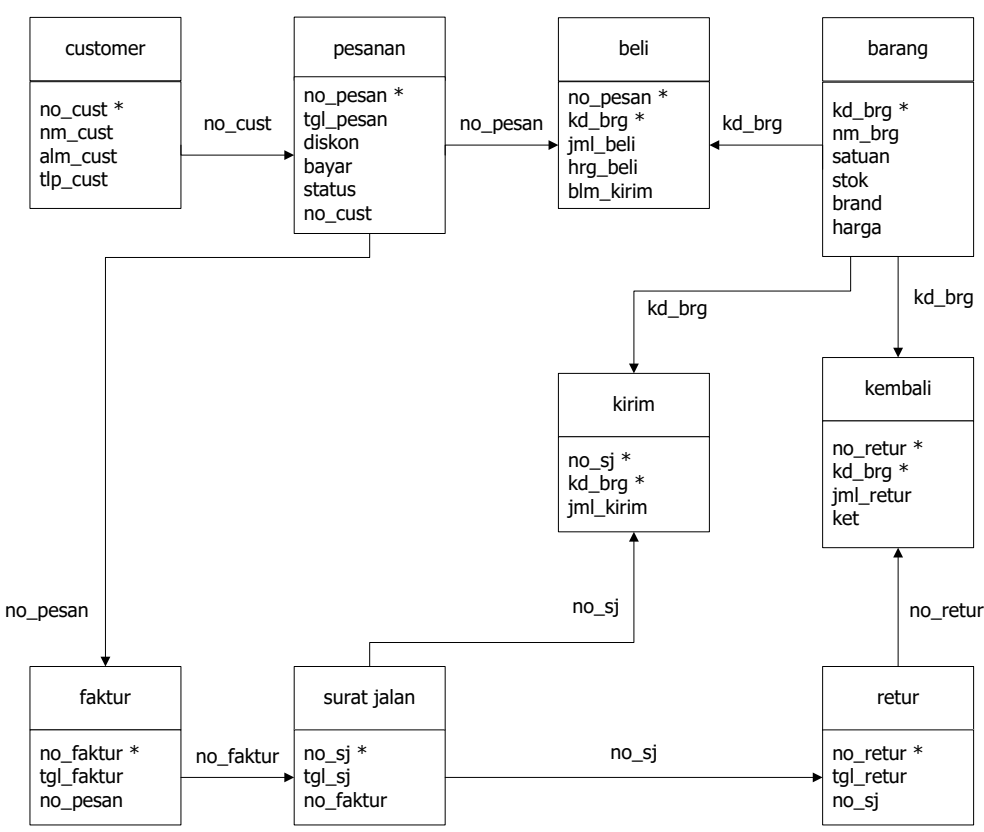

Gambar 6.Logical Record Structure

C. Struktur Tampilan

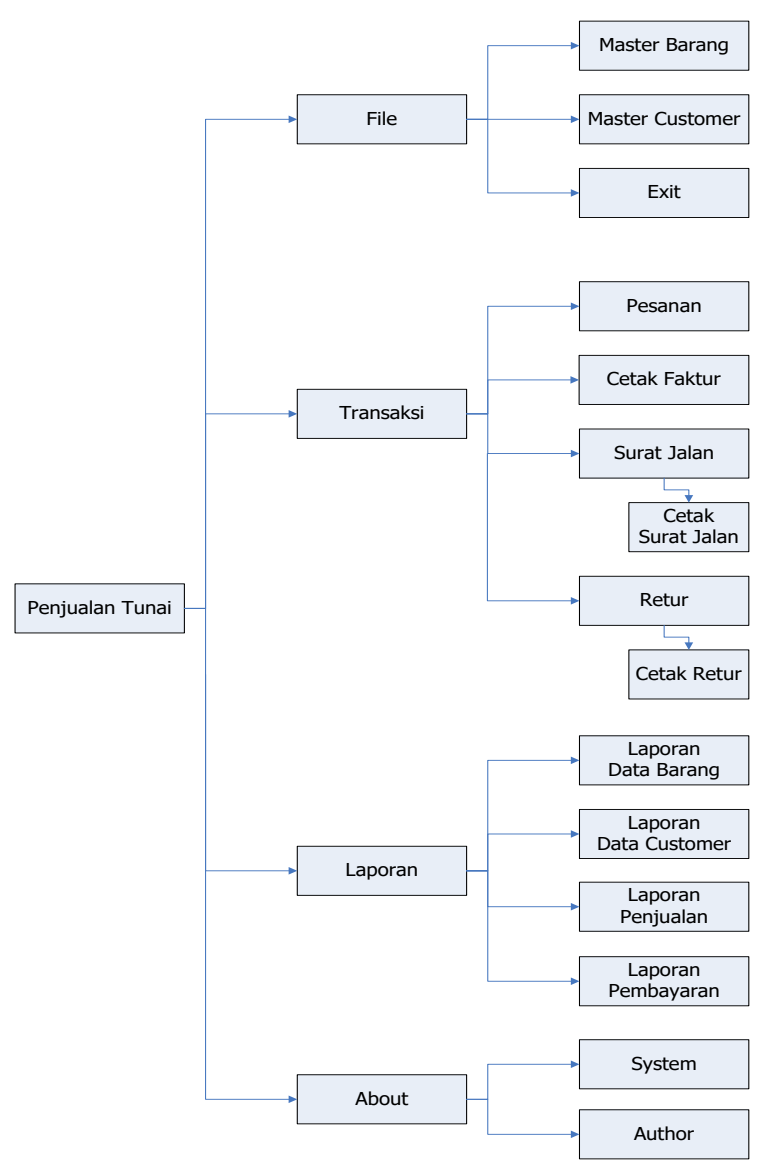

Gambar 7.Struktur Tampilan
III. KESIMPULAN

Berdasarkan pembahasan diatas, telah didapatkan suatu kesimpulan sebagai berikut :

a. Dengan penerapan sistem yang terkomputerisasi, tingkat keakuratan data yang tesimpan dapat lebih terjamin, seperti pada proses entry data barang yang apabila dilakukan dengan cara manual akan membutuhkan waktu yang lama.

b. Dengan adanya otomasi komputer maka proses pengurutan dan pencarian data akan semakin mudah dan cepat, sehingga dapat menghemat waktu.

c. Dengan penerapan sistem yang terkomputerisasi akan meminimalkan kesalahan pencatatan dan penulisan data maupun transaksi yang sering dilakukan.

d. Dengan diubahnya cara manual menjadi terkomputerisasi maka data-data penjualan yang ada lebih dapat terjaga dengan baik dari masalah kerusakan, kehilangan dan terselipnya data.

e. Dengan adanya sistem ini, pembuatan laporan menjadi lebih mudah, cepat dan akurat, karena proses pengurutan dan penghitungan data sudah terkomputerisasi.

\section{REFERENSI}

[1] [1]. Jogiyanto. 2005. Sistem Teknologi Informasi. Yogyakarta: Penerbit Andi.

[2] Kadir, Abdul. 2002. Penuntun Praktis Belajar SQL, Yogyakarta: Penerbit Andi. 
[3] Munawar. 2005. Pemodelan Visual dengan UML. Jakarta: Penerbit Graha Ilmu.

[4] Waljiyanto. 2003. Sistem Basis Data Analisis Dan Pemodelan Data. Yogyakarta: Penerbit Graha Ilmu. 